\title{
История становления и развития Лечебно-санитарного управления Кремля: проблемы изучения
}

\begin{abstract}
Аннотащия: Статья посвящена истории Лечебно-санитарного управления Кремля (1919-1953 г2.) - спеииального органа правительственной медииины, главными задачами которого являлись: 1) медичинское обслуживание высшего советского государственного и партийного руководства; 2) контроль санитарного состояния Московского Кремля, других мест расположения высших органов государственной власти и пребывания советского руководства при поездках по стране и на отдых. Рассматриваются проблемы степени изученности темы и перспективы ее исследования. Это многогранная тема, которая до сих пор комплексно не исследовалась. Лечсанупр Кремля изучался преимущественно в узкопрофессиональном аспекте. В исторической литературе сюжеты, связанные со здоровъем высшего руководства, затрагиваются преимущественно в свлзи отдельными персоналиями, например, В. И. Лениным, И. В. Сталиным и др. Изучение истории Лечсанупра Кремля актуально в контексте проблемы «медичина и власть». В настоящее время вылвлен значительный комплекс материалов, позволяющих исследовать различные аспекты проблемы истории системы медииинского обеспечения и отдыха советского руководства. В данной статье обозначены только некоторые из возможных проблем изучения. Представляется, что исследование данной темы приоткроет новые стороны советской политической истории и повседневной жизни советского руководства.
\end{abstract}

Annotation: The article focuses of the history of the Medical-Sanitary Department of the Kremlin (1919-1953) - the special branch of government's medical system that addressed the problems of: 1) medical care of the highest echelon of the Soviet government's administration; 2) sanitary control of the Moscow Kremlin and of other important government locations and places outside Moscow visited on trips and holiday locations. The author examines the degree of research done on the given topic, which despite its multidimensional aspects is still little studied, and the possibilities of future research. The MedicalSanitary Department of the Kremlin was studied primarily in a narrow professional aspect. The historiography on the health and medicine of the highest Soviet administration is primarily concentrated on individual figures as, for example, on V. I. Lenin, I. V. Stalin, and others. The study of the history of the Kremlin Medical-Sanitary Department should be considered in the wider historiographical problem of "medicine and power". Today a great body of material is available, which permits the research of the diverse aspects of the history of the Soviet power's system of medical care and vacationing. The article points to only several possible research topics, while the study of this question in general allows to uncover many new sides of the political history and daily life of the Soviet administration.

Ключевые слова: Лечсанупр Кремля, Московский Кремль, Лечебная комиссия ЦК, советское руководство, санатории, дома отдыха, лечение, санитарное состояние, медичина, власть.

Key Words: Kremlin Medical-sanitary Department, Moscow Kremlin, the Medical Commission of the Central Committee, soviet leadership, sanatoria, vacation centers, medical treatment, sanitation, medicine, power.

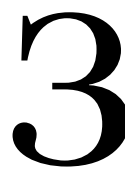
доровье, лечение, отдых первых лиц государства испокон веков являются отнюдь не частным делом. Эта проблема неотделима от политической истории страны, и есть немало примеров, когда такие «нюансы» непосредственно влияли на развитие политической ситуации. Еще в Древней Руси зарождается придворная медицина, а с течением времени она оформляется в Придворную медицинскую часть, задачей которой было обеспе- чение комплексной медицинской безопасности императора и его семьи. ${ }^{1}$

В советские годы также сложилась система медицинского обслуживания высшего государственного и партийного руководства, был создан специальный орган руководства правительственной медициной, носивший разные назва-

\footnotetext{
1 См. подробнее: Медицина и императорская власть в России. Здоровье императорской семьи и медицинское обеспечение первых лиц России в XIX - начале XX века. М., 2008.
} 


\section{Исторический журнал: научные исследования № 1 (19) 2014}

DOI: $10.7256 / 2222-1972.2014 .1 .12243$

ния: Лечебно-санитарное управление Кремля (Лечсанупр Кремля) - Четвертое главное управление при Министерстве здравоохранения СССР. Преемником последнего после распада Союза ССР стал Медицинский центр Управления делами Президента Российской Федерации (с 1992 г.) - Главное медицинское управление Управления делами Президента Российской Федерации (с 2004 г.).

Лечсанупр Кремля интересен как объект изучения в двух плоскостях, во-первых, как уникальный лечебный и научно-исследовательский комплекс, занимавший лидирующее положение в развитии отечественной медицины; во-вторых, как орган правительственной медицины, являвшийся частью целой системы обеспечения отдыха и лечения высшего советского государственного и партийного руководства. Изучение становления и развития Лечсанупра Кремля, несомненно, актуально в контексте проблемы «медицина и власть».

Деятельность Лечебно-санитарного управления Кремля приходится на 1919-1953 гг. Его главными задачами являлись: 1) медицинское обслуживание высшего советского государственного и партийного руководства; 2) контроль санитарного состояния Московского Кремля, других мест расположения высших органов государственной власти и пребывания советского руководства при поездках по стране и на отдых.

Современное состояние изученности данной темы можно оценивать как фрагментарное. Помимо объективной закрытости информации, связанной с частной стороной жизни первых лиц, в советские годы изучение многих тем в принципе табуировалось. Тем не менее, деятельность Лечсанупра Кремля нашла отражение в некоторых публикациях. С 1936 г. начал выходить сборник научных трудов Лечебно-санитарного управления Кремля², в котором публиковались результаты новейших медицинских разработок и научных исследований. К двадцатилетнему юбилею в сборник была включена статья о Лечсанупре Кремля, в которой прослеживались основные вехи его развития и содержался интересный фактический материал.

Наиболее обстоятельной работой в советской историографии по истории Лечсанупра

\footnotetext{
2 Труды экспериментальной лаборатории и курортных санаториев Лечсанупра Кремля. М., 1936; ХХ лет работы Лечебно-санитарного управления Кремля. Сборник трудов. М.; Л., 1939; Сборник научных трудов Лечебно-санитарного управления Кремля М., 1945; XXX лет работы Лечебно-санитарного управления Кремля. Сборник трудов. М.; Л., 1950.
}

Кремля представляется монография Г. П. Зарубина $^{3}$, которая хронологически охватывает только самый ранний период его деятельности с 1918 по 1921 гг. Свою задачу автор видел в «освещении вопросов возникновения и развития лечебного и санаторно-курортного дела в Кремле в первые годы Советской власти» и показе роли «выдающихся деятелей Советского государства - В. И. Ленина, М. И. Калинина, В. Д. Бонч-Бруевича, Н. А. Семашко и других - в деле создания медицинской службы Кремля». ${ }^{4}$ Г. П. Зарубиным впервые был введен в научный оборот значительный комплекс архивного материала и использованы другие доступные опубликованные источники, раскрывающие мероприятия по организации Лечсанупра и основные направления его деятельности в первые годы. В центре внимания находились санитарно-эпидемические проблемы, которые освещаются в контексте становления советской системы здравоохранения, работа насыщена фактическим и документальным материалом.

В постсоветское время авторский коллектив под руководством генерального директора Медицинского центра Управления делами Президента РФ С. П. Миронова подготовил работу ${ }^{5}$ по истории медицинского обслуживания первых лиц государства, в которой отдельный раздел посвящен деятельности Лечсанупра Кремля. ${ }^{6}$ Последовательно освещены вехи становления Лечсанупра Кремля как специального органа правительственной медицины, прошедшего путь от нескольких медицинских учреждений в Московском Кремле до целостной системы медицинских и лечебно-профилактических учреждений. Помимо организационных вопросов большое внимание уделено характеристике направлений научно-исследовательской работы в учреждениях Лечсанупра Кремля. В книге собраны сведения о руководителях Лечсанупра Кремля на протяжении всего периода его деятельности, о врачах и медицинских специалистах, работавших в его системе.

Таким образом, Лечсанупр Кремля изучался преимущественно в узкопрофессиональном аспекте. В исторической литературе сюжеты,

\footnotetext{
3 Зарубин Г. П. Санитарный надзор Кремля в первые годы Советской власти. М., 1967.

4 Там же. С. 7-8.

5 Кремлевская медицина (от истоков до наших дней) / С. П. Миронов, Ю. Л. Перов, В. М. Цветков, В. М. Ястребов. М., 1997.

6 Там же. С. 75-149.
} 
связанные со здоровьем высшего руководства, затрагиваются преимущественно в связи с отдельными персоналиями, например, В. И. Лениным $^{7}$, И. В. Сталиным ${ }^{8}$, дается оценка конкретных историй болезней. Вместе с тем, если обратиться к истории Лечсанупра в широком историческом контексте, то появляется немало новых малоисследованных аспектов политической и повседневной советской истории.

Интересный подход представляет работа врача В. Д. Тополянского ${ }^{9}$, который использовал «медицинский ключ» для понимания событий 1920-1930-х гг. В. Д. Тополянский дал профессиональную оценку доступным для исследования заключениям и справкам о состоянии здоровья советских руководителей и с медицинской точки зрения попытался объяснить мотивы поведения высшего руководства СССР. Автор, например, пишет, что «для объяснения феномена ежовщины имела значение лишь сопутствующая общему физическому инфантилизму задержка психического развития сталинского выдвиженца $\left[\right.$ т.е. Н. И. Ежова - O.К.)]». ${ }^{10}$ В книге большое внимание уделяется врачам, работавшим с первыми лицами, скрупулезно отслеживает их профессиональный путь, взаимоотношения между ними и другие нюансы. Лечсанупр Кремля В. Д. Тополянский рассматривает как орудие «тоталитарной медицины»: «Указание вождя мирового пролетариата само собой обратилось в краеугольный камень системы Лечебно-санитарного управления Кремля (впоследствии четвертого Главного управления Минздрава), лишний раз подтвердив, таким образом, что всякое начинание в казенной стране оплодотворяла директива». ${ }^{11}$ В этом контексте автор объясняет, например, смерть в 1925 г. М. В. Фрунзе. Большой интерес представляет профессиональный анализ операции, проведенной наркому по военным и морским делам, которая привела к

\footnotetext{
7 См., напр.: Лопухин Ю. М. Болезнь, смерть и бальзамирование В. И. Ленина: Правда и мифы. М., 1997.

8 В большинстве публикаций, обращающихся к теме здоровья Сталина, дискутируется проблема неестественной смерти Сталина в результате заговора его ближайшего окружения. См., напр.: Ноймаер А. Диктаторы в зеркале медицины. Ростов н/Д, 1997; Медведев Ж., Медведев Р. Неизвестный Сталин. 4-е изд. М., 2011; Чигирин И. Отец. «Тайна» смерти И.В. Сталина и неизвестные документы об известных событиях. М., 2012; Миронин С. С. Как отравили Сталина. Судебно-медицинская экспертиза. М., 2014.

9 Тополянский В. Д. Сквозняк из прошлого. М., 2009.

10 Там же. С. 495.

11 Там же. С. 472.
}

летальному исходу. ${ }^{12}$ В целом, работа В. Д. Тополянского отражает только одну из граней темы «медицина и власть».

Создание Управления санитарного надзора Кремля было продиктовано острой необходимостью. В марте 1918 г. советское правительство переехало из Петрограда в Москву, местом официальной резиденции становится Кремль. На его территории разместились высшие органы государственной власти и управления и поселились на постоянное проживание руководители государства, работники госучреждений, сотрудники кремлевской комендатуры, военнослужащие подразделений обеспечивающих охрану Кремля и многие другие.

Кремль превратился в один из густонаселенных «районов» столицы. Уже к середине лета 1918 г. в Московском Кремле постоянно проживало более 1100 человек, из которых 450 вселилось после революции. Жители «Кремлевского холма» заняли все хоть сколько-нибудь пригодные для проживания помещения. Это и архитектурные памятники - Сенат, Большой Кремлевский и Малый (Николаевский) дворцы, Потешный дворец, Кавалерский, Офицерский, Гренадерский, Кухонный и Синодальный корпуса, старая Оружейная палата, корпуса у Спасских ворот и у кремлевской стены, расположенные между Боровицкими и Троицкими башнями, флигели у Спасских ворот, Боровицкая и Спасская гауптвахты. Проживали в кремлевских башнях, во всех кремлевских соборах и монастырях, при действующих церквях и даже в колокольне Ивана Великого. Например, в здании Рабоче-крестьянского правительства (бывший Сенат), в котором находилась квартира В. И. Ленина, 262 жильца занимали полуподвал. ${ }^{13}$ Только в Большом Кремлевском дворце к концу 1918 г. официально прописались 59 человек. Например, в Детской половине дворца находились квартиры семей Я. М. Свердлова, А. И. Рыкова, В. В. Осинского; на Собственной половине К. Цеткин, в Белом (Фрейлинском) коридоре поселились Л. Б. Каменев, Д. И. Курский, С. Д. Петропавловский, Г. С. Сосновский, Демьян Бедный; в желтом коридоре - В. Р. Менжинский. Ф. Э. Дзержинский с супругой прописались в нижних апартаментах дворца; в так

\footnotetext{
12 Там же. С. 252-257; Тополянский В. Д. Гибель Фрунзе // Вопросы истории. 1993. № 6.

13 Московский Кремль - цитадель России. М., 2009. С. 210-
} 212. 


\section{Исторический журнал: научные исследования № 1 (19) 2014}

DOI: 10.7256/2222-1972.2014.1.12243

называемых «верхних» апартаментах 2-й этаж занимал А. В. Луначарский; 3-й этаж - К. Б. Радек и Е. Д. Стасова. К концу 1920 г. в Кремле получили прописку более 2100 человек. $^{14}$

С приездом большевиков от размеренного кремлевского быта прошлых столетий не осталось и следа. В рабочие дни Московский Кремль особенно преображался, жизнь в нем кипела. Количество советских служащих вместе с постоянно проживавшими в Кремле людьми доходило до 5 тыс. человек. Кроме этого, ежедневно в Кремль приходили многочисленные посетители. Только за 1919 г. комендатура выселила из Кремля более 1000 человек, прописав в него четыре сотни новых жителей. В то время в учреждениях Кремля работало 2238 человек, на пулеметных курсах, курсанты которых охраняли территорию, училось более 1200 человек. В среднем, ежемесячно, для прохода к проживающим в Кремле и посетителям кремлевских учреждений выписывалось 4000 пропусков. Например, за 1919 г. было выдано более 40 тысяч пропусков. ${ }^{15}$

Приехав в Москву, советское руководство застало свою новую резиденцию в плачевном состоянии. Последние ремонтные работы проводились в Кремле к юбилейным торжествам 1912-1913 гг. а революционные события довели его состояние до крайности. Самые драматичные дни пришлись на 27 октября - 3 ноября 1917 г., когда развернулись уличные бои, а Кремль подвергся артобстрелу. Пострадали практически все кремлевские соборы, церкви, здания, стены и башни. Одна треть окон стояла без стекол, кругом разбитые тротуары, сломанные решетки, несметное количество разбросанных ящиков, досок, мусорных куч. Положение обострялось эпидемиями болезней. Состояние Кремля особенно усугубилось в санитарном отношении после массового заселения. Небольшой отрывок из «Предписаний для жителей Кремля», подписанных управляющим делами СНК В. Д. Бонч-Бруевичем 14 октября 1918 года, более чем красноречив: «...грязь на дворах и площадях, домах, лестницах, коридорах и квартирах ужасающая. Мусор от квартир не выносится неделями, стоит на лестницах, распространяя заразу. Лестницы не только не моются, но и не подметаются. На дворах неделями валяется навоз, отбросы, трупы дохлых

\footnotetext{
14 Там же. С. 210.

15 РГАСПИ. Ф. 17. ОП. 86. Д. 249. Л. 4-4 об.
}

кошек и собак. Всюду бродят бездомные кошки, являясь постоянными носителями заразы. В городе ходит «испанская» болезнь, зашедшая и в Кремль и уже давшая смертные случаи. Болезнь эта требует соблюдения особой чистоты как на улицах, во дворах, на лестницах и помещениях...». ${ }^{16} \mathrm{~B}$ октябре 1918 г. в Потешном дворце Московского Кремля были организованы амбулатория и больница на 10 коек.

Санитарная обстановка в Кремле достигла критической черты уже к началу 1919 г. Проведенный специальной комиссией санитарный осмотр здания Рабоче-крестьянского правительства показал, что даже состояние кабинета Ленина, не говоря уже обо всем здании, не выдерживало критики: «В кабинете тов. Ленина также чистота весьма не достаточна, на шкафах, печках и на листах пальм находящихся в кабинете, масса пыли и по углам у потолка затянуто паутиной». ${ }^{17}$

Стало очевидно, что переломить ситуацию могут только экстренные меры. 18 февраля 1919 г., одновременно с созданием Управления санитарного надзора Кремля появляются «Санитарные правила для жителей Кремля», подписанные самим В. И. Лениным и наркомом здравоохранения Н. А. Семашко. Они включали в себя всего несколько пунктов и, по сути, предписывали элементарные правила гигиены: «Соблюдать личную чистоту и в помещениях». Одно из основных положений обязывало всех вновь приезжавших в Кремль «вымыться в бане и сдать свои носильные вещи дезинфектору». Игнорирование этих правил грозило немедленным выселением из Кремля и преданием суду «за нанесение общественного вреда». ${ }^{18}$

В своем развитии Лечсанупр Кремля прошел несколько этапов. Официальной датой его создания считается 18 февраля 1919 г., когда народный комиссар здравоохранения Н. А. Семашко и управляющий делами Совнаркома В. Д. Бонч-Бруевич подписали «План организации санитарного надзора Кремля» и «Устав Управления санитарного надзора Кремля». Управление санитарного надзора Кремля в административном и хозяйственном отношении находилось в ведении Управления делами СНК, а в медико-санитарном - в ведении Наркомздрава. 22 февраля 1919 г. начальником Управления

\footnotetext{
16 ГАРФ. Ф. Р-1235. ОП. 140. Д. 46. Л. 1.

17 ГАРФ. Ф. Р-130. ОП. З. Д. 350. Л. 3.

18 ГАРФ. Ф. Р-130. Оп. 3. Д. 350. Л. 18; Ленинские декреты по здравоохранению. М., 1980. С. 116-117.
} 


\section{История повседневности}

DOI: $10.7256 / 2222-1972.2014 .1 .12243$

был назначен санитарный врач Кремля доктор Я. Б. Левинсон ${ }^{19}$.

Управление санитарного надзора Кремля стало быстро развиваться, и его деятельность не ограничивалась только территорией Кремля. В конце 1919 г. на него было возложено обслуживание Домов Советов. ${ }^{20}$ Кроме этого, Управление санитарного надзора Кремля занималось медико-санитарным обеспечением важнейших государственных мероприятий, и это становится одним из направлений деятельности органов правительственной медицины.

В середине 1920 г. началось объединение всех медицинских учреждений Кремля под руководством Управления санитарного надзора Кремля: помимо амбулатории и больницы, имелась аптека, проходные бани, механическая прачечная, санитарно-пропускные пункты в Кремле и Домах Советов, сыпно-тифозная больница (ул. Б. Полянка) и др. В 1921 г. принимается новое Положение и Управление получает название «Санитарное управление Кремля и домов ВЦИК». Санитарное управление подразделялось на санитарно-эпидемиологический отдел (которому подчинялись дезинфекционный отряд, проходные бани и прачечная в Кремле, пропускные пункты Кремля и домов ВЦИК); лечебный отдел, возглавляемый старшим врачом Кремлевской больницы, руководившим постановкой лечебной работы во всех подведомственных учреждениях; административнохозяйственный и финансовый отделы.

В 1922 г. название управления было уточнено - Санитарное управление Кремля при Управлении делами Совнаркома (Санупр Кремля). Основные его задачи заключались в лечебном и санитарном обслуживании Кремля, домов ВЦИК, СНК и ЦК РКП(б), а также учреждений, подведомственных ВЦИК и Управлению делами СНК. Определился круг лиц, подлежащих

\footnotetext{
19 Левинсон Яков Борисович (1873-1947) - в 1919-1934 гг. начальник Управления санитарного надзора Кремля - Санитарного управления Кремля - Лечебно-санитарного управления Кремля; в 1934-1939 гг. - заместитель начальника Лечсанупра Кремля.

20 Домами Советов (ВЦИК) назывались, переданные для проживания сотрудников правительственных учреждений гостиницы и здания в Москве: «Националь» - I дом ВЦИК, «Метрополь»- II дом ВЦИК, здание Духовной семинарии на Садово-Каретной - III дом ВЦИК, «Петергоф» (угол Моховой и Воздвиженки) - IV дом ВЦИК, дом № 3 по ул. Грановского (ныне Романов переулок) - V дом ВЦИК; ул. Воровского, д. 11 VI дом ВЦИК; ул. Манежная, д. 9 - VII дом ВЦИК; и др., всего 12 домов, в которых помимо постоянных жителей размещалось большое количество приезжающих. (ГАРФ. Ф. Р-1235. Оп. 140. Д. 480. Л. 37).
}

персональному обслуживанию Кремлевской больницей и другими лечебными учреждениями Санупра Кремля. Персональное право лечения в Кремлевской больнице имели: наркомы и их заместители, члены ВЦИК, ЦК и ЦКК РКП(б), Исполкома Коминтерна и члены их семей, члены коллегий наркоматов, ЦК Союза молодежи, Президиума ВЦСПС, а также лица по списку, утвержденному ЦК РКП(б). Также на больницу возлагалось обеспечение медицинской помощью населения Кремля и сотрудников всех учреждений, располагавшихся на его территории, за исключением воинских частей. ${ }^{21}$ Санитарно-бактериологическое обеспечение военных частей обеспечивалось Санитарным отделом Управления комендатуры Московского Кремля.

В 1925 г. Кремлевская больница переезжает на ул. Воздвиженка, и здесь же организуется поликлиника. В Кремле осталась только небольшая амбулатория для оказания неотложной помощи и стоматологический кабинет.

В деятельности Санупра, когда он находился на территории Кремля, выделяется несколько аспектов для изучения. Во-первых, именно тогда формируются основные принципы системы медицинского обеспечения советского руководства, возложенного на Санитарное управление Кремля, за которым закрепляется статус органа при правительстве РСФСР - СССР. Во-вторых, эта уникальная страница истории Московского Кремля, а также срез истории советской повседневности первых послереволюционных лет. Например, в годы гражданской войны Кремль и его жителей не обошли такие инфекционные заболевания, как сыпной и брюшной тиф, натуральная оспа, дизентерия и др. ${ }^{22}$ Эпидемиологическая ситуация в целом по стране была крайне тяжелой. Например, одной из жертв разразившихся эпидемий стала И. Ф. Арманд, умершая в 1920 г. от холеры. Для решения санитарных проблем и удобства жителей в Кремле были созданы проходные бани, которые, например, за 1919 г. пропустили 35138 чел. (жители и приезжающие) ${ }^{23}$

Архивные материалы, хранящиеся в фондах Государственного архива Российской Федерации ${ }^{24}$, раскрывают особенности становления и развития Санупра Кремля, статистику заболе-

\footnotetext{
21 Кремлевская медицина (от истоков до наших дней). C. 86-87.

22 Зарубин Г. П. Указ. соч. С. 78-80.

23 Там же. С. 113.

24 ГА РФ. Ф. Р-130, Р-1235.
} 


\section{Исторический журнал: научные исследования № 1 (19) 2014}

DOI: 10.7256/2222-1972.2014.1.12243

ваний в правительственной резиденции и др. Материалы включают штатные расписания, приказы, распоряжения, переписку Санупра с управделами ВЦИК, Совнаркомом, отчетность Санупра Кремля, сведения о заболевших, дезинфекционных и профилактических мероприятиях; и др.

1 октября 1928 г. Санитарное управление Кремля реорганизуется в Лечебно-санитарное управление Кремля (Лечсанупр Кремля). В декабре 1935 г. Лечсанупр Кремля передается из ведения Совнаркома СССР в подчинение Наркомздрава РСФСР, а с июля 1936 г. - Наркомздрава CCCP.

В 1930-е гг. Лечсанупр Кремля обслуживал всеми видами медицинской помощи сотрудников учреждений ЦИК СССР и ВЦИК, СНК СССР и РСФСР, ЦК ВКП(б) и Коминтерна, а также осуществлял санитарный надзор Кремля и правительственных зданий в Москве. В 1938 г. в лечебных учреждениях Лечсанупра Кремля обслуживалось 24300 чел. К концу 1947 г. количество обслуживающихся в поликлиниках Лечсанупра Кремля достигло 28 тыс. Было решено пересмотреть списки, и к концу 1948 г. число лиц снизилось до 22,5 тыс. чел. ${ }^{25}$

Помимо лечебной деятельности Лечсанупр Кремля занимался медицинским обслуживанием санаториев и домов отдыха ВЦИК СССР и ВЦИК, СНК СССР и РСФСР. Еще в начале 1920-х гг. создаются санаторно-курортные учреждения для отдыха и лечения работников правительственных организаций. В административно-хозяйственном отношении они находились в ведении ВЦИК и Совнаркома, а руководство их медицинской деятельностью было возложено на Санитарное управление Кремля. В его ведении находились медицинские части домов отдыха ЦИК СССР, ВЦИК, СНК СССР и РСФСР в Сочи, Крыму, Кавказских Минеральных водах и др. К концу 1935 г. в ведении Лечсанупра Кремля находились медицинские части 46 домов отдыха. ${ }^{26}$

Санаторно-курортное лечение и отдых высших советских руководителей - тема, требующая самостоятельного изучения. В Российском государственном архиве социально-политической истории (РГАСПИ) выявлен большой комплекс материалов, связанный с этой проблемой. В частности, это документы Политбюро, Оргбюро, Секретариата ЦК РКП - ВКП(б), касаю-

\footnotetext{
25 Кремлевская медицина (от истоков до наших дней). C. 102-103, 132.

26 Там же. С. 91, 98.
}

щиеся строительства домов отдыха, курортов, предоставления отпусков, направления на лечение и др. Ценным источником для изучения проблемы являются материалы личных фондов И. В. Сталина, К. Е. Ворошилова, А. С. Енукидзе, М. И. Калинина, В. М. Молотова и др. В частности, интересные сведения о здоровье содержатся в переписке, которая носила не только деловой, но и личный характер. Вот, например, отрывок из письма Г. К. Орджоникидзе, находившегося в отпуске, К. Е. Ворошилову от 12 июля 1928 г.: «Дорогой друг, Клим! Как живешь, как здоровье? Что у вас там нового и как прошел Пленум? Бубнов ${ }^{27}$ мне рассказал о твоих головных болях. Вот видишь, брат, меня ругаешь, что не слежу за собой, а сам всех отпустил в отпуск и один сидишь там за всех. Да, мой дорогой, так легче: ругать других мы все умеем, а за собой смотреть никто. Когда же ты все-таки думаешь отдохнуть? Вернулась ли Ек. Дав. ${ }^{28}$ и как она себя чувствует? Мы тут живем ничего себе, но почки мои довольно бессовестно пошаливают. За это время было три довольно тяжелых приступа. В Москве найдена коховская палочка, здесь проверяют...». ${ }^{29}$ А вот письмо Г. К. Орджоникидзе от 1 июня 1929 г.: «Здравствуй, дорогой Клим! Как живете? Как дела? Съезд, как видно из газет, как будто прошел хорошо... Когда ты думаешь уйти в отпуск и куда? Здесь место для отдыха прекрасное. Были бы бесконечно рады видеть тебя у нас в Мухалатке. ${ }^{30}$ Погода здесь довольно хорошая, хотя часто туманы, не очень жарко. Мы тут живем, как у Христа за пазухой...». ${ }^{31}$

В настоящее время переписка советских руководителей введена в научный оборот частично $^{32}$ и как источник по данной теме практически не исследовалась. Из опубликованных архивных

\footnotetext{
27 Бубнов Андрей Сергеевич (1884-1938) - в 1924-1929 гг. начальник Политического управления РККА; в 1925 г. - секретарь ЦК РКП(б); член ВЦИК, ЦИК СССР; в 1929-1937 гг. народный комиссар просвещения РСФСР.

28 Ворошилова Екатерина Давидовна (1887-1959) - жена К. Е. Ворошилова.

29 РГАСПИ. Ф. 74. ОП. 2. Д. 43. Л. 30.

30 Государственная дача в Крыму.

31 РГАСПИ. Ф. 74. ОП. 2. Д. 43. Л. 48.

32 Письма И. В. Сталина В. М. Молотову. 1925-1936 гг. Сборник документов / Сост. Л. Кошелева, В. Лельчук, В. Наумов, О. Наумов, Л. Роговая, О. Хлевнюк. М., 1995; Сталинское Политбюро в 30-е гг.: сборник документов / Сост. О. В. Хлевнюк и др. М., 1995; Большевистское руководство. Переписка. 1912-1927 / Ред. А. В. Квашонкин. М., 1996; Советское руководство. Переписка. 1928-1941 / Сост. А. В. Квашонкин, Л. П. Кошелева, Л. А. Роговая, О. В. Хлевнюк. М., 1999; Сталин и Каганович. Переписка. 1931-1936 гг. / Сост. О. В. Хлевнюк и др. М., 2001.
} 


\section{История повседневности}

DOI: $10.7256 / 2222-1972.2014 .1 .12243$

материалов РГАСПИ, также следует выделить комплекс документов, связанных с развитием курортного дела в г. Сочи. ${ }^{33}$

Деятельность Лечсанупра Кремля следует рассматривать как одну из составляющих системы лечения и отдыха высшего советского государственного и партийного руководства. До сих пор практически не исследовался вопрос о взаимоотношениях между Лечсанупром Кремля и Лечебной комиссией ЦК, через которую проходили все вопросы, касающиеся направления советского руководства на лечение, отдых, и даже в отпуск. Основанием для этих решений служили медицинские заключения Лечсанупра. Если обратиться к архивным материалам, то особенно активно лечебные вопросы поднимались на заседаниях Политбюро, Секретариата и Оргбюро ЦК во второй половине 1920-х - 1930-е гг., когда сложившаяся система медицинского обеспечения высшего советского руководства активно развивалась. Отложившиеся материалы свидетельствуют, что к проблемам здоровья советское руководство относилось очень внимательно; если не удавалось вылечиться силами отечественной медицины, приглашали заграничных специалистов или отправляли лечиться за рубеж. Например, в 1929 г. Политбюро приняло решение о вызове врачей из Германии для лечения серьезно заболевшего Г. К. Орджоникидзе. Однако, эта идея не вызвала у него энтузиазма, в письме И. В. Сталину от 22 июня 1929 г. из Мухалатки он писал: «Дорогой Сосо! Розанов и Федоров ${ }^{34}$ расскажут тебе о состоянии моего здоровья. Я прошу тебя и других товарищей отказаться от вызова немцев, в этом нет абсолютно никакой необходимости. Я чувствую себя прекрасно, прямо стыдно своей рожи. Врачи мне чертовски надоели, хочется отдохнуть без них, тем более, что они совершенно беспомощны. В дальнейшем все зависит исключительно от моего организма...». ${ }^{35}$ В итоге его желание было учтено, о чем ему написал Сталин 1 июля 1929 г.: «Мухалатка. Орджоникидзе. Получил все письма. Говорил с Федоровым и Розановым. Тебе уже известно,

\footnotetext{
33 См. подробнее: Борисёнок Ю., Кошелева Л. «Сочи строятся дорого, но хорошо» // Родина. 2008. № 1-2.

34 Розанов Владимир Николаевич (1872-1934) - хирург, профессор, лечащий врач В.И. Ленина и И.В. Сталина; в 19281934 гг. руководитель хирургического стационара Кремлевской больницы; Федоров Сергей Петрович (1868-1936) - хирург, в 1903-1936 гг. возглавлял кафедру госпитальной хирургии Военно-медицинской академии.

35 РГАСПИ. Ф. 558. Оп. 11. Д. 777. Л. 96.
}

что вопрос о немецких врачах исчерпан в духе твоего предложения...». ${ }^{36}$

В тоже время политическую жизнь страны сотрясала борьба за власть, и фактор «здоровья» в ней также имел место. Например, Л. Д. Троцкий на страницах своих мемуаров, неоднократно ссылается на проблемы со здоровьем как причину упущенных шансов в борьбе со своими оппонентами. В частности, он слег с простудой в 1923 г., когда произошло резкое ухудшение здоровья В. И. Ленина, и эти же причины помешали ему присутствовать на похоронах вождя в январе 1924 г. ${ }^{37}$ Любопытно объяснение Троцким мотивов принятия решения о поездке на лечение за границу после снятия с постов председателя Реввоенсовета и народного комиссара по военным и морским делам СССР: «Весною 1926 г. мы совершили с женою путешествие в Берлин. Теряясь перед затяжной моей температурой, московские врачи, чтоб не брать на себя всей ответственности, давно настаивали на заграничной поездке. Я тоже хотел найти выход из тупика: температура парализовала меня в наиболее критические моменты и являлась надежным союзником моих противников. Вопрос о поездке за границу рассматривался в Политбюро. Оно высказалось в том смысле, что по всем имеющимся у него данным и по всей политической обстановке считает мою поездку крайне опасной, но окончательное решение предоставляет мне самому. $К$ решению приложена была справка ГПУ в духе недопустимости моей поездки за границу. Политбюро, несомненно, опасалось, что в случае каких-либо неприятных приключений со мной за границей ответственность будет возложена партией на него. Мысль о принудительной высылке меня за границу, притом в Константинополь, тогда еще не осеняла полицейской головы Сталина. Возможно, что Политбюро опасалось также каких-либо действий моих за границей по части сплочения иностранной оппозиции. Так или иначе, но, посоветовавшись с друзьями, я решил ехать». .38

К закрытой части темы относятся персональные истории болезни ${ }^{39}$, хотя частично некоторые

\footnotetext{
36 Там же. Д. 37. Л. 83.

37 Троцкий Л.Д. Моя жизнь. М., 2006. С. 481, 484-485, 494497.

38 Там же. С. 508-509.

39 Основной комплекс историй болезни находится на секретном хранении в Центральном архиве Управления делами Президента РФ (до января 2013 г. - Центральный медицинский архив Управления делами Президента РФ) - бывшем Центральном медицинском архиве Четвертого главного управления при Министерстве здравоохранения СССР.
} 


\section{Исторический журнал: научные исследования № 1 (19) 2014}

DOI: $10.7256 / 2222-1972.2014 .1 .12243$

из них, например, В. И. Ленина и И. В. Сталина, рассекречены. Кроме этого, имеются медицинские заключения и справки по отдельным заболеваниям некоторых советских руководителей, что дает возможность для освещения, например, проблемы взаимоотношений между Лечсанупром Кремля и Лечебной комиссией ЦК, и др.

История Лечебно-санитарного управления Кремля - многогранная тема, которая до сих пор комплексно не исследовалась. В настоящее вре- мя выявлен значительный пласт источников, позволяющих исследовать различные аспекты проблемы истории системы медицинского обеспечения и отдыха советского руководства. В данной статье обозначены только некоторые из возможных проблем изучения. Представляется, что данная тема актуальна и перспективна, ее исследование приоткроет новые стороны советской политической истории и повседневной жизни советского руководства.

\section{Библиография:}

1. Борисёнок Ю., Кошелева Л. «Сочи строятся дорого, но хорошо» // Родина. 2008. № 1-2.

2. ХХ лет работы Лечебно-санитарного управления Кремля: Сборник трудов. М.; Л., 1939.

3. Зарубин Г. П. Санитарный надзор Кремля в первые годы Советской власти. М., 1967.

4. Кремлевская медицина (от истоков до наших дней) / С. П. Миронов, Ю. Л. Перов, В. М. Цветков, В. М. Ястребов. М., 1997.

5. Ленинские декреты по здравоохранению. 1917-1921. 2 изд. М., 1980.

6. Московский Кремль - цитадель России / С. В. Девятов, А. В. Дёмкин, В. И. Жиляев, О. К. Кайкова и др. М., 2009.

7. Тополянский В. Д. Сквозняк из прошлого. М., 2009.

8. Тополянский В. Д. Гибель Фрунзе // Вопросы истории. 1993. № 6.

9. Троцкий Л. Д. Моя жизнь. М., 2006.

10. Цветков В. М. Деятельность Лечебно-санитарного управления Кремля в годы Великой Отечественной войны // Клинический вестник. 1995. № 4.

\section{References:}

1. Borisenok Yu., Kosheleva L. «Sochi stroyatsya dorogo, no khorosho» // Rodina. 2008. № 1-2.

2. XX let raboty Lechebno-sanitarnogo upravleniya Kremlya: Sbornik trudov. M.; L., 1939.

3. Zarubin G. P. Sanitarnyi nadzor Kremlya v pervye gody Sovetskoi vlasti. M., 1967.

4. Kremlevskaya meditsina (ot istokov do nashikh dnei) / S. P. Mironov, Yu. L. Perov, V. M. Tsvetkov, V. M. Yastrebov. M., 1997.

5. Leninskie dekrety po zdravookhraneniyu. 1917-1921. 2 izd. M., 1980.

6. Moskovskii Kreml' - tsitadel' Rossii / S. V. Devyatov, A. V. Demkin, V. I. Zhilyaev, O. K. Kaikova i dr. M., 2009.

7. Topolyanskii V. D. Skvoznyak iz proshlogo. M., 2009.

8. Topolyanskii V. D. Gibel’ Frunze // Voprosy istorii. 1993. № 6.

9. Trotskii L. D. Moya zhizn'. M., 2006.

10. Tsvetkov V. M. Deyatel'nost' Lechebno-sanitarnogo upravleniya Kremlya v gody Velikoi Otechestvennoi voiny // Klinicheskii vestnik. 1995. № 4 . 